\title{
AKTIVITAS PEMASARAN TABUNGAN PADA PT. BANK PEMBANGUNAN DAERAH SUMATERA BARAT CABANG PEMBANTU TARUSAN
}

\author{
Nurfazila, Doni Marlius \\ Akademi Keuangan dan Perbankan Padang \\ Nurfa99zila@gmail.com
}

\begin{abstract}
The purpose of this study was to determine the product marketing activities at PT. West Sumatra Regional Development Bank Branch Assistant Tarusan. The data used in this study is to directly interview the parties involved in this case are the companies involved. In analyzing the data, the author uses quantitative data analysis method as a research method that explains in a description of the savings marketing activities at PT. West Sumatra Regional Development Bank Branch Assistant Tarusan. The method of analysis is reviewed from two different aspects, namely between theory and practice so that it can be seen the extent of the implementation, whether differences arise regarding the basic principles of the concept itself. Conclusion PT. The West Sumatra Regional Development Bank Branch of Tarusan, using marketing consisting of product policies, prices, promotions, places, people, processes, customer service. The type of product provided by PT. The West Sumatra Regional Development Bank Branch of Tarusan is a SIKOCI savings, current accounts, deposits. Promotion conducted by PT. Regional Development Bank of West Sumatra, Branch of Tarusan through advertising (advertising), sales promotion (sales promotion), personal sales (personal selling).
\end{abstract}

Keywords : Savings Marketing Activities

\section{LATAR BELAKANG}

Perkembangan dunia perbankan yang diiringi pula dengan tumbuhnya minat masyarakat untuk menggunakan produk yang ditawarkan dengan teknologi yang modern, sehingga masyarakat memiliki banyak pilihan untuk transaksi keuangan dan investasi dengan cepat dan tepat. Perbankan sudah dianggap sebagai suatu kebutuhan

dan mitra dalam menjalankan bisnis. Karena itu, bank juga sangat berperan penting untuk membantu nasabah-nasabahnya dalam bertransaksi yang berhubungan dengan keuangan.

Adapun yang di maksud dengan perbankan adalah segala sesuatu yang menyangkut tentang bank, kelembagaan, kegiatan usaha, serta cara dan proses dalam melaksanakan kegiatan usahanya. Menurut pasal 1 Undang-Undang nomor 10 tahun 1998 adalah badan usaha yang menghimpun dana dari masyarakat dalam bentuk 
simpanan dan menyalurkannya kepada masyarakat dalam bentuk kredit dan bentukbentuk lainnya dalam rangka meningkatkan tarif rakyat banyak (Muhamad Rahman, 2015).

Maka dari itu adanya pemasaran untuk masyarakat yang belum mengetahuinya. Maksud dari pemasaran adalah suatu rangkaian proses kegiatan yang tak hanya mencakup penjualan terhadap barang atau jasa yang dihasilkan perusahaan jasa dimana kegiatan tersebut hanya pada penjualan tetapi jauh mendalam dari itu kegiatan pemasaran merupakan kegiatan yang dilakukan pada waktu sebelum maupun sesudah kegiatan penjualan barang atau jasa terjadi. Menurut firdaus mengemukakan pemasaran merupakan kegiatan yang dilakukan oleh banyak orang seperti halnya pengusaha guna mempertahankan hidup serta memenuhi kebutuhan.

Pada umumnya tujuan dari kegiatan pemasaran adalah mempengaruhi konsumen agar bersedia membeli produk saat mereka membutuhkanya. karena itu, setiap perusahaan harus berusaha meningkatkan pelayanan sebagai prasarana dan barang sebagai penyangga dalam menarik hati minat nasabah.

Chandler (1962) dalam Hunger dan Wheelen (2003:21), strategi merupakan alat untuk mencapai tujuan perusahaan dengan tujuan jangka panjang. Program tindak lanjut, serta prioritas alokasi sumber daya. Learned, Christensen, Andrews, dan Guth (1965) dalam Hunger dan Wheelen (2003:22) bahwa strategi merupakan alat untuk menciptakan keunggulan bersaing. karena itu strategi dapat menentukan apakah bisnis harus dilakukan atau tidak.

Menurut (Nova \& Lestari, 2019) strategi pemasaran adalah pengambilan keputusan-keputusan tentang biaya pemasaran, bauran pemasaran, alokasi pemasaran dalam hubungan dengan keadaan lingkungan yang diharapkan dan kondisi pesaing. strategi pemasaran ini mempunyai ruang lingkup yang luas dibidang pemasaran diantaranya adalah strategi menghadapi persaingan. Dalam pasar untuk produk jasa perbankan sangatlah luas, sehingga perusahaan atau bank tidak mudah untuk memasuki pasar yang sedemikian luas. Pasar yang luas ini perlu untuk dipilah-pilah agar mempermudah perusahaan dalam melakukan kegiatan pemasaran. Karena pasar yang luas maka sebelum melakukan kegiatan pemasaran harus dilakukan terlebih dahulu riset pasar, yang bertujuan untuk mengetahui seberapa besar yang akan dimasuki, siapa yang menjadi konsumen produk tersebut.

Promosi adalah sasaran paling ampuh untuk menarik dan mempermudahkan nasabahnya. Salah satu tujuan promosi bank adalah menginformasikan segala jenis produk yang ditawarkan dan berusaha menarik calon nasabah baru. Kemudian promosi juga berfungsi mengingatkan nasabah untuk membeli dan akhirnya promosi juga akan meningkatkan citra bank di mata para nasabahnya. Promosi menyangkut pemasangan iklan, penjualan personal, publisitas, serta sales promotion, aktivitas promosi memainkan peranan penting dalam menempatkan posisi produk di mata dan benak pembeli. Promosi memberitahukan, mengingatkan dan membujuk pembeli serta pihak lain yang berpengaruh dalam proses pembelian (Aryanto, 2009).

Strategi promosi adalah kegiatan yang direncanakan dengan maksud membujuk, konsumen agar mau membeli produk perusahaan sehingga tujuan untuk 
meningkatkan penjualan diharapkan dapat tercapai. Strategi yang dipakai oleh perusahaan untuk mengubah atau menyempurnakan produk yang ada sekarang menjadi bentuk yang lebih baik. Bentuk-bentuk promosi yang dilakukan PT. Bank Pembangunan Daerah Sumatera Barat Cabang Pembantu Tarusan berupa: melakukan iklan (Advertising) melalui brosur, produk dan reaklame. Kepuasan nasabah dapat ditentukan dengan kualitas produk yang ditawarkan dan layanan yang diberikan, sehingga jaminan dari kualitas produk menjadi hal utama yang paling diprioritas bagi pihak bank.

PT. Bank Pembangunan Daerah Sumatera Barat Cabang Pembantu Tarusan merupakan sebagai salah satu bank umum yang memiliki peranan penting dalam bentuk menghimpun dana dari masyarakat yaitu: tabungan, deposito dan giro. Berdasarkan Alasan dipilihnya PT. Bank Pembangunan Daerah Sumatera Barat Cabang Pembantu Tarusan sebagai obyek dalam penelitian ini dikarenakan PT. Bank Pembangunan Daerah Sumatera Barat Cabang Pembantu Tarusan mempunyai pertumbuhan jumlah nasabah tabungan yang meningkat tiap tahun. Hal ini mengindikasikan adanya peningkatan kinerja yang signifikan dan makin besarnya potensi bisnis yang ada. Simpanan tabungan nasabah pada 5 tahun belakangan ini pada PT. Bank Pembangunan Daerah Sumatera Barat Cabang Pembantu Tarusan dapat dilihat pada tabel dibawah ini .

Tabel 1

Perkembangan Jumlah Nasabah Tabungan dan Saldo Nominal PT. Bank Pembangunan Daerah Sumatera Barat Cabang Pembantu Tarusan Tahun 2015-2019

\begin{tabular}{ccc}
\hline Tahun & $\begin{array}{c}\text { Jumlah Nasabah } \\
\text { (orang) }\end{array}$ & $\begin{array}{c}\text { Saldo Nominal } \\
(\mathbf{R p .})\end{array}$ \\
\hline 2015 & 8.267 & 14.095 .872 .108 \\
2016 & 9.393 & 13.426 .442 .914 \\
2017 & 9.094 & 13.919 .785 .531 \\
2018 & 11.571 & 16.120 .287 .665 \\
2019 & 12.838 & 18.748 .545 .251 \\
\hline
\end{tabular}

Sumber: PT. Bank Pembangunan Daerah (BPD) Sumatera Barat Cabang Pembantu Tarusan

Dari tabel 1 diatas dapat dilihat perkembangan jumlah nasabah pada tahun 2015 tabungan yang dimiliki adalah sebanyak 8.267 orang dengan nominal 14.095.872.108,- pada tahun 2016 mengalami kenaikan jumlah nasabah sebanyak 9.393 orang dengan nominal 13.426.442.914,- pada tahun 2017 mengalami penurunan jumlah nasabah sebanyak 9.094 orang dengan nominal 13.919.785.531, pada tahun 2018 dan 2019 mengalami peningkatan jumlah nasabah dan juga nominalnya. 
Berdasarkan diuraikan diatas, penulis tertarik untuk melakukan penelitian dalam bentuk tugas akhir yang berjudul "Aktivitas Pemasaran Tabungan Pada PT. Bank Pembangunan Daerah Sumatera Barat Cabang Pembantu Tarusan”.

\section{METODE PENELITIAN}

Untuk keperluan penelitian ini, pengumpulan data dilakukan dengan dua cara yaitu:

1. Studi Perpustakaan (Library Research)

Yaitu penelitian ini dilakukan dengan cara mempelajari buku-buku, makalah-makalah, artikel-artikel, bacaan laporan-laporan dan publikasi yang berhubungan dengan objek penelitian

2. Studi Lapangan (Field Research)

Yaitu melakukan penelitian langsung untuk pengumpulan data-data dari PT. Bank Pembangunan Daerah Sumatera Barat Cabang Pembantu Tarusan dengan melakukan wawancara langsung dengan pihak bank tesebut

\section{HASIL DAN PEMBAHASAN \\ Pengertian Bank}

Bank merupakan perusahaan yang bergerak dibidang keuangan, artinya aktivitas perbankan selalu berkaitan dibidang keuangan, seperti yang telah ditegaskan (Pratika, 2019). Menurut Undang-undang RI Nomor 10, 1998 Tentang Perbankan yang dimaksud dengan bank adalah badan usaha yang menghimpun dana dari masyarakat dalam bentuk simpanan dan menyalurkannya kepada masyarakat dalam bentuk kredit dan atau bentuk-bentuk lainnya dalam rangka meningkatkan taraf hidup rakyat banyak (Yosefrisal, 1998).

Menurut (Ferdy \& Afriyeni, n.d.) berdasarkan jenisnya bank terdiri dari dua jenis yaitu bank umum dan bank Perkreditkan Rakyat (BPR). Perbankan di Indonesia saat ini terdapat beberapa jenis perbankan seperti yang diatur dalam Undang-Undang perbankan. Jika kita lihat jenis perbankan sebelum keluar Undang-Undang perbankan Nomor 10 tahun 1998 dengan sebelumnya, yaitu Undang-Undang perbankan Nomor 14 tahun 1967, maka terdapat beberapa perbadaan. Namun kegiatan utama pokok bank sebagai lembaga keuangan yang menghimpun dana dari masyarakat dan menyalurkan dana tidak berbeda satu sama lainnya

\section{sumber - Sumber dana Bank}

Menurut Kasmir (2011:65) sumber-sumber dana bank adalah usaha bank dalam menghimpun dana untuk membiayai operasinya. Asal dana bersumber dari bank itu sendiri, yang didapat dari setoran modal pemegang saham dan laba pada tahun lalu yang tidak dibagi kepada pemegang sahamnya (Intan Mayang Sari, 2019).

Sedangkan menurut Dr. kasmir 2014 Sumber-sumber dana bank adalah usaha bank dalam memperoleh dana dalam rangka membiayai kegiatan operasionalnya. Sesuai fungsi bank sebagai lembaga keuangan dimana kegiatan sehari-hari adalah bergerak dibidang keuangan, maka sumber-sumber dana juga tidak terlepas dari bidang keuangan. 


\section{Fungsi Bank}

Kegiatan bank umum

Merupakan bank yang paling bank beredar di Indonesia, bank umum banyak memiliki keunggulan dari pada BPR, baik dalam bidang pelayanan maupun jangkauan wilayah operasinnya. Adapun kegiatan bank umum sebagai berikut:

a. Menghimpun dana

Merupakan kegiatan membeli dana dari masyarakat, kegiatan membeli dana dapat dilakukan dengan cara menawarkan berbagai jenis simpanan. Jenis simpanan yang ada yaitu:

a) Simpanan giro

Merupakan simpanan pada bank yang penarikanya dapat dilakukan mengunakan cek atau bilyet giro.

b) Simpanan tabungan

simpanan pada bank yang penarikan sesuai dengan persyaratan yang ditetapka oleh bank.

c) Simpanan deposito

Merupakan simpanan yang memiliki jangka waktu tertentu (jatuh tempo).

b. Menyalurkan dana

Merupakan kegiatan menjual dana yang berhasil dihimpun dari masyarakat. Jenis dana yang disalurkan berbentuk kredit yaitu:

a) Kredit investasi

Merupakan kredit yang diberikan kepada pengusaha yang melakukan investasi.

b) Kredit modal kerja

Merupakan kredit yang digunakan sebagai modal usaha. Jangka waktu yang diberikan berjangka pendek yaitu tidak lebih dari 1 (satu) tahun.

c) Kredit produktif

Merupakan kredit yang dapat berupa investasi, modal kerja atau perdangang.

d) Kredit konsumtif

Merupakan kredit yang digunakan untuk keperluan pribadi minsalnya keperluan konsumsi, kredit perumahan, kredit kendaraan bermotor.

\section{Pengertian pemasaran}

Pemasaran merupakan proses sosial, baik individu maupun kelompok, untuk mendapatkan apa mereka butuhkan dan inginkan dengan menciptakan, menawarkan, secara bebas mempertukarkan produk dan jasa yang bernilai dengan pihak lain, agar proses menjual produk dapat berjalan sesuai harapan (Maulana, n.d.). Sedangkan menurut Philip dan Duncan pemasaran adalah sesuatu yang meliputi semua langkah yang dipakai, dibutuhkan untuk menempatkan barang bersifat tangible ke tangan konsumen.

Dalam melakukan pemasaran produk tabungan yang bertanggung jawab yaitu marketing funding, marketing funding adalah salah satu bagian pekerjaan di dunia perbankan memiliki fungsi serta tugas memperkenalkan, mempromosikan, meluaskan jaringan/relasi, untuk memasarkan produk dana. Maka marketing funding ditarget 
oleh bank untuk dapat mengumpulkan dana nasabah sebanyak-banyaknya melalui tabungan, giro, deposito akhirnya akan disalurkan kembali oleh pihak bank dalam bentuk pinjaman.

\section{Strategi Pemasaran}

Menurut cravens dan piercy (2003:31-32) mengemukakan bahwa pemasaran merupakan proses market-driven pengembangan strategi yang mempertimbangkan perubahan lingkungan dan kebutuhan untuk menawarkan superior costumer value (Aziz, 2016).

Strategi pemasaran merupakan serangkaian tujuan dan sasaran, kebijakan, aturan yang memberi arah kepada usaha-usaha pemasaran perusahaan dari waktu ke waktu, pada masing-masing tingkatan dan acuan serta alokasinya, terutama sebagai tanggapan perusahaan menghadapi lingkungan dan keadaan persaingan selalu berubah. (Asdi \& Rizal, 2019). Oleh karena itu strategi pemasaran merupakan kombinasi dari bauran pemasaran haruslah diatur sedemikian rupa sehingga dapat berfungsi sebagai senjata yang tepat di pasar melawan pesaing-pesaingnya.

Strategi memperhatikan secara sungguh-sungguh pengadaan keunggulan kompetitif, secara ideal berkelanjutan sepanjang waktu, tidak maneuver teknis dengan menggunakan perspektif jangka panjang secara keseluruhan (Cahyaningsih, 2018).

Untuk dapat menunjang peningkatan jumlah nasabah konsumen maka diperlukan suatu strategi pemasaran tepat dan terarah yang dilakukan oleh PT. Bank Pemabngunan Daerah Sumatera Barat Cabang Pembantu Tarusan sebagai berikut:

1. Strategi berdasarkan segmentasi pasar

Yaitu dengan membagi pasar kekelompok-kelompok sejenis dan memilih yang paling sesuai bagi bank dalam upayanya memberikan pelayanan yang terbaik dan menarik bagi nasabah. Minsalnya untuk kolompok pengusaha diperkenalkan giro, untuk pelajar diperkenalkan produk tabungan .

2. Strategi pemasaran berdasarkan Market Positioning

Yaitu dengan menambah ciri-ciri tertentu bagi produk-produk antara lain memudahkan persyaratan menabung dan penarikan tabungan serta memberikan tingkat bunga yang tetap bersaing dengan tingkat bunga pasar.

3. Strategi berdasarkan struktur pasar

Bagi suatu perusahaan sebelum menawarkan dan memasarkan, biasanya terlebih dahulu harus mengetahui peluang dan potensi pasar tersebut, maka perusahaan akan dapat memperkirakan tingkat penjualan yang akan dicapai. salah satu cara utuk melihat peluag dan potensi tersebut yaitu mempelajari struktur pasar, sebab struktur pasar ini merupakan pedoman dalam menyusun strategi dalam menghadapi persaingan.

Strategi untuk menetapkan keputusan yang berhubungan dengan pemasarn adalah strategi produk, strategi produk dipakai oleh perusahaan untuk mengubah atau menyempurnakan produk yang ada sekarang menjadi bentuk yang lebih baik. Salah satu strategi produk, strategi promosi juga merupakan suatu bagian yang sangat 
penting, promosi adalah suatu cara langsung untuk mempengaruhi konsumen agar lebih suka membeli merk barang tertentu.

\section{Bauran Pemasaran (marketing Mix)}

Menurut Lupiyoadi, Hamdani (2006:70) bauran pemasaran merupakan alat bagi pemasaran terdiri berbagai unsur suatu program pemasaran yang perlu dipertimbangkan agar implementasi strategi pemasaran dan positioning yang ditetapkan dapat berjalan sukses (Doni, 2016). Menurut (Neldi, 2012) bauran pemasaran adalah variable-variabel pemasaran yang dapat diatur sedemikian rupa sehingga dapat meningkatkan penjualan perusahaan variable-variabel tersebut terdiri dari produk (product), tempat (price), harga (place) dan promsosi (promotion), proses (process), orang (people), customer service.

Aktivitas pemasaran dilakukan, menggunakan pemasaran yang terdiri dari produk, harga, promosi, tempat, orang, alur kerja, layanan pelanggan.

1. Produk (product)

Menurut Kotler dan Armstrong (2008:62) adalah kombinasi barang dan jasa ditawarkan perusahaan kepada pasar sasarannya. Produk merupakan suatu sifat yang kompleks dapat dikatakan kompleks karena produk dapat diraba maupun tidak dapat diraba, termasuk warna, harga, dan pengecer dan pelayanan yang diterima pembeli untuk memuaskan keinginan dan kebutuhan. (Neldi, 2012)

Jenis-jenis produk PT. Bank Pembangunan Daerah Sumatera Barat Cabang Pembantu Tarusan:

\section{a. Tabungan SIKOCI}

Keunggulan Tabungan SIKOCI:

a) Otomatis dijamin asuransi jiwa

b) Dapat dijadikan sarana pembayaran listrik, telepon, air, uang kuliah PBB dan pajak lainnya.

c) Dapat ditark pada semua ATM PT. Bank Pembangunan Daerah Sumatera Barat atau melalui ATM bersama diseluruh Indonesia.

Persyaratan

a) Mengisi formulir aplikasi permohonan pembukaan rekening tabungan SIKOCI.

b) Foto copy KTP, SIM/paspor (WNA)

c) Setoran awal dan saldo minimal Rp.25.000- atau sesuai ketentuan

b. Tabunganku

Tabunganku diperuntukan bagi semua lapisan masyarakat diutamakan para penabung dari pelajar dan mahasiswa, keunggulan tabunganku antara lain :

1) Bunga bersaing

2) Dapat digunakan sebagai sarana pembayaran listrik, air, telepon, dan pajak lainnya

3) Tidak dikenakan biaya administrasi

4) Menerbitkan buku tabungan sebagai bukti tabunganku

Persyaratan : 
a) Mengisi formulir aplikasi permohonan pembukaan rekening tabungan tabunganku.

b) Storan awal RP 20.000

c) Bebas biaya administrasi

c. Tabungan SIMPEDA (Simpanan Pembangunan Daerah)

Tabungan SIMPEDA merupakan salah satu bentuk kerja sama PT. Bank Pembangunan Daerah seluruh Indonesia dalam bentuk tabungan bersama. Tabungan Simpeda memiliki keunggulan antara lain :

1) Bunga bersaing, dihitung dari saldo harian

2) Undian berhadiah 2 kali setahun

3) Kesempatan memperoleh hadiah lebih besar

4) Dapat menarik, menyetor serta pemindahbukuan di semua kantor Cabang Pembangunan Daerah sesuai ketentuan yang berlaku

5) Pengambilan dan penyetoran dapat dilakukan setiap hari kerja

6) Dapat dijadikan sarana pembayaran air, Listrik, Telepon, Uang kuliah, PBB, Pajak lainnya.

Persyaratan :

a) Mengisi formulir aplikasi untuk membuka

b) Foto copy identitas KTP, SIM/Paspor (WNA)

c) Setoran awal dan saldo minimal Rp 10.000 atau sesuai dengan ketentuan berlaku

d) Biaya administrasi sesuai dengan peraturan yang berlaku

d. Giro

Yaitu simpanan yang penarikannya dapat dilakukan setiap saat dengan mengunakan cek, bilyet giro, sarana perintah pembayaran lainnya atau dengan cara pemindahbukuan

Keunggulan giro PT. Bank Pembangunan Daerah (BPD) Sumatera Barat Cabang Pembantu Tarusan

a) Meningkkatkan citra dan bonafiditas perusahaan/perorangan

b) Pembayaran dilaksanakan dengan cepat dan tepat

c) Giro dalam bentuk rupiah dan valuta asing

d) Jasa giro bersaing

e) Mempermudahkan pembayaran untuk, pembayaran listrik, telepon, air, uang kuliah dll.

f) Kirim uang (transfer) dalam dan luar negeri.

Persyaratan :

a) Mengisi formulir aplikasi pembukuan rekening

b) Foto copy identitas KTP, SIM/Paspor (WNA)

c) Menyerahkan Akte Pendirian dan SIUP

d) Foto copy NPWP

e) Tidak termasuk dalam daftar hitam bank Indonesia

e. Deposito

Keunggulan deposito PT. Bank Pembanguan Daerah Sumatera Barat: 
a) Pelayanan yang cepat dan tepat

b) Deposito dalam rupiah dan valuta asing

c) Bunga dapat diambil setiap bulan atau pindah bukuan ke rekening tabungan anda

d) Jangka waktu dapat dipilih 1 bulan, 3 bulan, 6 bulan, 12 bulan dan 24 bulan

e) Perpanjang secara otomatis

Persyaratan :

a) Mengisi formulir aplikasi pembukuan deposito

b) Foto copy identitas KTP.SIM/Paspor (WNA)

2. Harga (Price)

Menurut (Zulkarnaen, 2012) harga merupakan satu-satunya unsur bauran pemasaran yang menghasilkan pendapatan, dan unsur-unsur lainnya menghasilkan biaya. tujuan dari penentuan harga secara umum menurut kotler adalah:

a. Struktur biaya

b. Persaingan

c. Sasaran yang ingin dicapai perusahaan

d. Kondisi ekonomi

3. Promosi (promotion)

Menurut (Ida Farida, Achmad Tarmizi*, 2016) promosi merupakan kegiatan yang dilakukan perusahaan untuk berkomunikasi dengan para pelanggan dan konsumen sasaran, menjalin kerja sama antar perusahaan serta masyarakat luas. Promosi adalah kegiatan yang dilakukan perusahaan dengan tujuan utama menginformasikan, membujuk, mempengaruhi, dan mengingatkan konsumen mau membeli produk yang dihasilkan (Putri \& Susanto, n.d.). Menurut denny, (2013) promosi adalah jenis komunikasi yang memberikan penjelasan, meyakinkan calon konsumen tentang barang dan jasa dalam bertujuan untuk perhatian, mendidik, mengingatkan, dan menyakinkan calon konsumen (Rara Riezka Hidayati, 2014). Sarana promosi dapat digunakan setiap perusahaan dalam mempromosikan produknya, baik barang maupun jasa, promosi tersebut adalah:

a. Periklanan (Advertising)

b. Kegiatan promosi penjualan (sales promotion)

c. Penjualan pribadi (personal selling)

4. Tempat (place)

Menurut (Sari, 2019) tempat yaitu berbagai kegiatan perusahaan membuat produk yang dihasilkan/dijual terjangkau dan tersedia bagi pasar sasaran. Pada PT Bank Pembangunan Daerah Sumatera Barat Cabang Pembantu Tarusan ini dinilai strategis karena dekat dengan penduduk, pasar, sekolah, instansi pemerintah dan pedagang

5. Orang-orang yang terlibat dalam aktivitas pemasaran(people)

Merupakan tipe kualitas dan kuantitas orang yang terlibat dalam pemberian jasa. Dalam pemasaran jasa people yang berfungsi sebagai pelayanan jasa sangat mempengaruhi kualitas yang diberikan. Keputusan dalam people ini berarti 
sehubungan dengan seleksi, perhatian, motivasi dan manajemen sumber daya manusia (MSDM).

6. Alur Kerja (process)

Proses merupakan gabungan semua aktivitas, umumnya terdiri dari prosedur, jadwal kerja, mekanisme, aktivitas produk dan jasa bank disampaikan kepada nasabah. Prosedur pelaksanaan, mekanisme kerja. Alur pelayanan nasabah dan hal-hal lain bersifat rutin (Amelia \& Widayati, 2019)

7. Layanan pelanggan

Untuk meningkatkan pelayanan pada masyarakat atau nasabah seperti menyediakan tempat/kantor dan ruang tunggu yang memadai, dengan tata ruang nyaman hingga nasabah merasa nyaman bila memasuki kantor.

\section{KESIMPULAN DAN SARAN \\ Kesimpulan}

Berdasarkan uraian yang telah dikembangkan pada bab-bab terdahulu, maka penulis dapat menyampaikan beberapa kesimpulan mengenai aktivitas pemasaran tabungan yang dilakukan oleh PT. Bank Pembangunan Daerah Sumatera Barat Cabang Pembantu Tarusan sebagai berikut :

1. aktivitas pemasaran produk tabungan yang dilakukan PT. Bank Pembangunan Daerah Sumatera Barat Cabang Pembantu Taruan menentukan produk, teknik pemasaran, melakukan promosi, serta saluran distribusi dalam pemasaran produk tabungan bertanggung jawab dalam memasarkan produk adalah Marketing Funding juga menggunakan konsep 7P : product, Price, Promotion, Place, People, Process, Physical Evldence.

2. Jenis produk yang diberikan PT. Bank Pembangunan Daerah Sumatera Barat Cabang Pembantu Tarusan Tabungan SIKOCI

3. Perkembangan jumlah nominal tabungan dari tahun 2015 sampai tahun 2017 mengalami peningkatan setiap tahunnya tapi pada tahun 2017 mengalami penurunan, dapat dilihat bahwa nominal tabungan lebih besar dibandingkan dengan biaya promosi yang dikeluarkan PT. Bank Pemabngunan Daerah Sumatera Barat Cabang Pembantu Tarusan.

\section{Saran}

Berdasarankan kesimpulan di atas, maka penulis dapat memberikan saran sebagai berikut :

1. Meningkatkan strategi pemasaran pruduk-produk yang ditawarkan oleh PT. Bank Pembangunan Daerah Sumatera Barat Cabang Pembantu Tarusan guna meningkatkan kepercayaan masyarakat kepada PT. Bank Pembangunan Daerah Sumatera Barat Cabang Pembantu Tarusan khususnya dalam produk tabungan.

2. PT. Bank Pembangunan Daerah Sumatera Barat Cabang Pembantu Tarusan harus menciptakan promosi yang lebih gencar lagi untuk menarik calon nasabah seperti melakukan saluran promosi melalui komunikasi dari mulut ke mulut dan melakukan promosi melalui media televisi. 


\section{UCAPAN TERIMAKASIH}

Dengan menyebut nama Allah SWT yang maha pengasih lagi maha penyayang, penulis ucapkan puji dan syukur atas kehadirat-nya, yang telah melimpahkan rahmat, hidayahnya kepada saya. Penulis ingin menyampaikan terima kasih yang tak terhingga atas bimbingan bapak Doni Marlius SE,MM yang telah memberikan motivasi, masukan-masukan maupun kritik-kritik dan dukungan secara moril ataupun material dan untuk sahabat terbaik terimaksih untuk semangat dan dukungannya yang sangat berguna untuk Tugas Akhir. Akhir kata penulis ucapkan terimah kasih, semoga apa yang penils tuangkan dalam karya kecil ini memberikan manfaat terutama bagi saya sendiri selaku penulis. Amin ya Rabbal'alamin

\section{DAFTAR PUSTAKA}

Amelia, R., \& Widayati, R. (2019). Aktivitas Pemasaran Produk Simpanan PT. Bank Tabungan Negara (Persero) Tbk Kantor Cabang Padang. Akademi Keuangan Dan Perbankan Padang, 1(1), 1-9. https://osf.io/preprints/5x2c4/

Asdi, \& Rizal, S. (2019). Strategi Pemasaran Produk Tabungan Simpedes Dalam Meningkatkan Jumlah Nasabah Pada PT. Bank Rakyat Indonesia (Persero) Tbk. Kantor Cabang Sungguminasa. Bongaya Journal for Research In Management, $2,17-25$.

Aziz, R. N. (2016). Strategi Analisis Strategi Pemasaran Produk Tabungan BNI Syariah Kantor Cabang Bumi Serpong Damai. Jurusan Manajemen Fakultas Ekonomi Dan Bisnis.

Cahyaningsih, D. (2018). Strategi Pemasaran Produk Simpanan Pelajar (SIMPEL)

Pada PT. BPR Eka Bumi Artha Kpo Metro. Jurusan Perbankan Syariah Fakultas Ekonomi Dan Bisnis Islam.

Dr, \& Kasmir. (2014). Dasar-Dasar Perbankan. PT. RajaGrafindo Persada. Ferdy, \& Afriyeni. (n.d.). Aktivitas Pemasaran Produk Tabungan Pada PT. Bank

Pembangunan Daerah (BPD) Sumatera Barat Cabang Utama Padang. Akademi Keuangan Dan Perbankan Padang.

Fure, J. A. (2016). Fungsi Bank Sebagai Lembaga Keuangan Di Indonesia Menurut Undang-Undang Nomor 10 Tahun 1998 Tentang Perbankan. V(4), 116-122.

Hidayati, R. R., \& Marlius, D. (2018). Aktivitas Promosi Dalam Meningkatkan Dana Pihak Ketiga Pada PT. Bank Perkreditan Rakyat (BPR) Batang Kapas Pesisir Selatan. https://doi.org/10.31227/osf.io/8dgqn

Ida Farida , Achmad Tarmizi*, \& Y. N. F. (2016). Analisis Pengaruh Bauran Pemasaran 7P Terhadap Kepuasan Pelanggan Pengguna Gojek Online. Jurnal Riset Manajemen Dan Bisnis, 1(1), 31-40. https://doi.org/10.36226/jrmb.v1i1.8

Intan Mayang Sari, A. (2019). Aktivitas Penghimpunan Dana Tabungan Pada PT. Bank Pembangunan Daerah (BPD) Sumatera Barat Cabang Utama Padang. Akademi Keuangan Dan Perbankan Padang, 1-10. https://doi.org/10.31219/osf.io/ackfh

Kharisma, I. (2008). Pengaruh Kinerja Keuangan Terhadap Roa Pada Bank Pemerintah. Jurusan Manajemen, 4(672013167), 0-18. 
Marlius, D. (2017). Keputusan Pembelian Berdasarkan Faktor Psikologis Dan Bauran Pemasaran Pada PT. Intercom Mobilindo Padang. Jurnal Pundi. Volume 1. No. 1. Hal. 57-66. https://doi.org/10.31575/jp.v1i1.9

Marlius, D. (2016). Pengaruh Bauran Pemasaran Jasa Terhadap Minat Nasabah Dalam Menabung Pada Bank Nagari Cabang Muaralabuh. https://doi.org/10.31227/osf.io/vdqgx

Maulana, E. H. dan H. (n.d.). Peranan Strategi Pemasaran Bank Dalam Upaya Meningkatkan Nasabah. Universitas Ibn Khaldun Bogor, 47-57.

Muhamad Rahman, R. W. (2015). Aktivitas Pemasaran Produk Tabungan Pada PT. BPR Rangkiang Denai Payakumbuh Barat. Akademi Keuangan Dan Perbankan Padang.

Neldi, V. (2012). Bauran Promosi Pada PT. Bank Syariah Mandiri Cabang Jambi. Politeknik Negeri Padang Jurusan Administrasi Niaga, 7(June), 1-25.

Pratika, I. (2019). Pengaruh Aktivitas Promosi Dalam Menarik Minat Nasabah Pada PT. Bank Rakyat Indonesia (PERSERO), Tbk. Cabang Makassar Panakkukang. 1(4), 1-21.

Putri, V. D., \& Susanto, R. (n.d.). Aktivitas Pemasaran Produk Bank Pada PT. Bank Perkreditan Rakyat (BPR) Cempaka Mitra Nagari Padang. Akademi Keuangan Dan Perbankan Padang, 1-14.

Sari, J. (2019). Strategi Pemasaran Produk Tabungan IB Siaga. Program Studi D-III Perbankan Syariah Fakultas Ekonomi Dan Bisnis Islam, 53(9), 1689-1699. https://doi.org/10.1017/CBO9781107415324.004

Sinuhaji, E. (2010). Penerapan Layanan Unggul Dalam Pemasaran Produk Bank. Jurnal Mediasi, 2(1).

Syaifuddin, D. D. T. (2007). Manajemen Perbankan. Penerbit Unhalu Press.

Yosefrisal, M. S. . T. (1998). Aktivitas Pemasaran Produk Tabungan Pada PT. Bank Perkreditan Rakyat Gajah Tongga Koto Piliang Silungkang. Akademi Keuangan Dan Perbankan Padang, 10, 1-22.

Zulkarnaen, H. O. (2012). Analisis Strategi Pemasaran Pada Usaha Kecil Menengah (UKM) Makanan Ringan. Fakultas Ekonomi Dan Bisnis, 2015.

Aryanto, D. Y. (2009). Aktivitas Promosi Kedai Digital 10 Surakarta. Jurusan Ilmu Komunikasi Fakultas Ilmu Sosial Dan Politik, 10.

Nova, \& Lestari. (2019). Efektivitas Strategi Pemasaran Produk Tabungan IB Tapenas Pada BNI Syariah Cabang Bengkulu. Jurusan Ekonomi Islam Fakultas Ekonomi Dan Bisnis Islam, 4(1), 75-84. https://doi.org/.1037//00332909.I26.1.78 